\title{
THE CHALLENGES OF RIGHT TO MEMORY AND TRUTH
}

\section{OS DESAFIOS DO DIREITO À MEMÓRIA E À VERDADE}

\section{SANDRA REGINA MARTINI}

Post PhD in Law, Post PhD in Public Policies, PhD in Legal Systems and New Laws. Professor and Coordinator of the Human Rights Master's Degree Program (Uniritter). E-mail: srmartini@terra.com.br.

\section{DAILOR DOS SANTOS}

Doctoral candidate in Public Law, Master of Public Law - New Laws, Specialist in State Law, Professor of Constitutional and Administrative Law (Universidade Feevale), Judicial Analyst at the Brazilian Federal Justice Court. E-mail: dailorsantos@gmail.com.

\begin{abstract}
Objectives: The present study deals with the discussion of the construction of political memory, questioning if the Law has sufficiency to fully develop the Right to Memory. The question is how the ethics of memory should be defined and analyzed, as well as whether the Law is open to the plurality of speeches about the past so that the right to memory and truth can be guaranteed.
\end{abstract}

Methodology: The study is based on bibliographic research and adopts in its approach the hypothetical-deductive method, through the interpretation of scientific articles and studies, also seeking a historical perspective.

Results: One of the conclusions of the study refers to the construction of political memory, which requires a conciliatory meaning to be given to the Right to Memory and Truth, based on a new ethical appropriation. Brazilian transitional policies are insufficient, which indicates the reason for its inconclusive democratic statement. An ethics of memory must contemplate all reports emerging from the past; that the Law must admit the perspectives that transitional practices are based on their intrinsic composition, endorsing historical facts that cannot be refuted in the future. The political 
memory is a perspective of social identity and belonging, based on an ethical refusal to deny history.

Contributions: The article addresses a topic less discussed in Brazil and, from various perspectives, questions whether the law can keep its current codes and remain closed to diversity and plurality, showing that the right to memory and truth will only be limited to the moments allowed by Transitional Justice, where memory is considered as an opportunity to summarize the past. , which will tolerate the repetition of dichotomist appropriations.

KEYWORDS: Right to memory and truth; fraternal law; transitional justice; political memory; ethics.

\section{RESUMO}

Objetivos: O presente estudo trata da discussão da construção da memória política, questionandoe se o Direito tem suficiência para desenvolver plenamente o Direito à Memória. Indaga-se como deve ser definida e analisada a ética da memória, bem como se o Direito está aberto à pluralidade de discursos sobre o passado para que 0 Direito à Memória e à Verdade possa ser garantido.

Metodologia: $\mathrm{O}$ estudo alicerça-se em pesquisas bibliográficas e adota em sua abordagem o método hipotético-dedutivo, por intermédio de interpretação de artigos científicos e estudos, buscando também uma perspectiva histórica.

Resultados: Uma das conclusões do estudo refere-se à construção da memória política, que exige um sentido conciliatório a ser conferido ao Direito à Memória e à Verdade, baseado em uma nova apropriação ética. As políticas transicionais brasileiras são insuficientes, o que indica a razão de sua afirmação democrática inconclusa. Uma ética da memória deve contemplar todos os relatos que emergem do passado; que o Direito deve admitir as perspectivas que as práticas transicionais assentam em sua intrínseca composição, endossando fatos históricos que não podem, no futuro, ser refutados. A memória política é uma perspectiva de identidade e pertencimento sociais, a partir de uma recusa ética à negação da história.

Contribuições: $O$ artigo aborda um tema pouco discutido no Brasil e, em diversas perspectivas, questiona se o Direito pode manter seus atuais códigos e permanecer fechado à diversidade e pluralidade, mostrando como consequência que o direito à memória e à verdade estarão somente limitados aos instantes permitidos pela Justiça Transicional, onde a memória é considerada como uma oportunidade para resumir o passado, que tolerará a repetição de apropriações dicotomistas. 
PALAVRAS-CHAVE: Direito à memória e à verdade; Direito fraterno; justiça de transição; memória política; ética.

\section{INTRODUCTION}

The affirmation that there is a Right to Memory and Truth is certainly not satisfied with its own self-recurrence. Transitional Justice in Brazil, for example, demonstrates the difficulties of a juridical and political construction of memory and truth. Even today, the transitional Brazilian practice, unmistakably destined to inventory the violence wounds left by the military dictatorship regime, clashes with an unsatisfactory dichotomy ${ }^{1}$ : those who only admit the recovery of violent routines disseminated and accepted by the State, with legal punishment for the agents of the state (or whoever took on this role) on one side; and on the other side those who accuse objectors of the military dictatorship regime of aiming to implement their own political agenda, opposed to democracy, as well as equally having created victims with their violent and allegedly insurrectional actions.

This dichotomy is easily identified in several public debates regarding the limits of political remembrance. A clear example of this opposition of merit - unsatisfactory in its own origin and dynamics, and on the other hand clarifying the difficulty for an authentic national reconciliation - occurred when the National Truth Commission, created by Law 12.528 on November 18, 2011², defined that its scope of examination and clarification would only cover the actions taken by the agents of the State that violated human rights, without the need to investigate acts by the resistance. The speakers were not randomly chosen, as they clearly identify, within the extremes of

\footnotetext{
${ }^{1}$ The understanding of Bobbio on a dichotomy is adopted: a distinction that admits a compartmentation of the universe being analyzed into two distinct and antagonistic portions. Therefore, an excluding and irreconcilable differentiation (BOBBIO, 2003).

${ }^{2}$ According to Article 1 of Law 12.528 dated 18.11.2011: Within the Civil House of the Presidency of the Republic, the National Commission on Truth is created, with the goal of examining and clarifying severe human rights violations perpetrated during the period set by article 8 of the Act on Transitional Constitutional Dispositions, in order to effect the right to memory and historical truth and promote national reconciliation. (BRASIL, 2011).
} 
right and left (as if these were the only ideological concepts that define reality), the difficulty for political remembrance. On one side Paulo Abrão, National Justice Secretary and President of the Amnesty Commision in 2012; and on the other side Rômulo Bini Pereira, an Army general. For Paulo Abrão, "Acts by the resistance should not be investigated. It was their legitimate right to fight against the legitimate order and oppression. The Truth Commission is suited to investigate the crimes perpetrated by the State. Those committed by the body that should protect citizens and not persecute them" (O GLOBO, 2012). Although this address was made on March 2, 2012, new resistance rose against it, this time on June 7,2016, undeniably showing the persistence of the dichotomy (the myth of being affiliated to one of the sides; the good or the bad; the "good guys" or the "bad guys") and, therefore, the difficulty of giving an inclusive or conciliatory meaning to the Right to Memory. The following address was made by Rômulo Bini Pereira: "On the Truth Commission, its 'verdict' has harmed the basic principle of Justice: due process of law. All because it investigated only the violations perpetrated by the agents of the State. It has established a unilateral truth, a clear legal aberration that has caused the commission to be discredited before the public opinion" (ESTADÃO, 2016). With subtle derivatives, this is the scenario in which Brazilian transitional presents itself.

The construction of political memory in Brazil, understood in an implicit dichotomy, as abovementioned explained, also happens between two distinct juridical positions. It deals with comparing the understanding of the Brazilian Supreme Court which states that the Amnesty Law of 1979 was in compliance with the Constitution of 1988, and the position of the Inter-American Court of Human Rights, which acknowledges the abuse perpetrated in Brazil during the military dictatorship regime, and imposes on the country - going in an opposite direction compared to the Brazilian Supreme Court - "The criminal investigation of the facts of the present case in order to ascertain them, determine those criminally responsible, and effectively apply the punishment and consequences which the law dictates" (BRASIL, 2010).

An allegation of unconstitutionality (ADPF 153), filed by the Brazilian Bar Association (OAB), gave the Brazilian Supreme Court the opportunity to examine the 
compatibility of the Amnesty Law with the Brazilian Federal Constitution of 1988, in other words, whether the oblivion orchestrated in 1979 would resist an analysis under the democratic nature of the 1988 Constitution or not. So, what did the highest Court of the country decide during the course of the Brazilian transitional process? It decided that Amnesty Law, conceived as a specific law for that historical period, was in compliance by the Brazilian constitutional text, thus excluding any attempts at weakening provisions set forth by the Amnesty Law of 1979, which, in the end, would have represented the necessary path towards social peace and achievement of the democratic constitutional order of 1988.

If for the Brazilian Supreme Court, clinging to the idea of a legal measure ${ }^{3}$ in order maintain the Amnesty of 1979 was enough, the Inter-American Court of Human Rights (IACHR), in an opposite way, understood that "the State must take into consideration that these crimes are imprescriptible and cannot be the object of amnesty. That is the reason why Brazil must take all necessary measures to ensure that Amnesty Law and secrecy laws cease to represent an obstacle for criminal persecution"4, ultimately settling both the existence of conflicting understanding and the great difficulty Brazil presents in dealing, internally, with its political memory, and, consequently, in conferring any sense to Right to Memory. The same comprehension was adopted by the IACHR in 2018, when Brazil was considered responsible for the violation of the right to the truth in the case concerning the murdering, committed by the Brazilian State in 1979, of the journalist Vladimir Herzog (CORTE IDH, 2018).

One would reasonably argue that this manichean clash, and even the different understandings held by the Inter-American Court on Human Rights and the Brazilian Supreme Court, would not reflect, on its own, the totality of the political phenomenon of remembrance, nor would it oppose the affirmation of memory as a Fundamental Human Right that necessarily needs to be preserved. However, the continuous and

\footnotetext{
${ }^{3}$ This expression is ambiguous. It is written as lei-medida in Portuguese, therefore, a law created to regulate certain social situations in a certain timeframe.

4 The IACHR has made progress on this subject matter, determining that Brazil investigate the facts, judge and punish all responsible persons of committing severe violations against Human Rights. The Brazilian State must remove all obstacles - such as those related to Amnesty Law - that maintain the impunity status of those who have violated Human Rights (CORTE IDH, 2010).
} 
still existing opposition between advocates and objectors of remembrance, along with the different understandings between the Brazilian Supreme Court and the InterAmerican Court on Human Rights, introduces a deeper questioning: regardless of the ethical claims of memory, what does Right to Memory and Truth really mean in the juridical framework? In other words: is Law prepared to give meaning to political memory? In case it is prepared, what juridical and political meaning could it confer to remembrance and why does it still allow for dichotomic appropriations? On the other hand, in case it is not prepared, what would explain the existence of the mentioned dichotomy, what is missing for Law to understand the dynamics of building the past?

These questions exceed the mere analysis of the Brazilian transitional practice, although, in this Article, they use this example exactly because of their abovementioned peculiarities. Thus, such questions lead to the problem around giving meaning to Right to Memory and, also reveal two major obstacles that must be faced, and which are imposed upon every State that have, to a lesser or higher degree, carried out transnational policies. These obstacles are: (I) building a memory ethics that is able to confer meaning to the mnemonic phenomenon and to its political configuration and (II) understanding the limits and real possibilities that Law itself confers to the perspective of remembrance, that is, if Law is sufficiently prepared and opened to combining plural testimonies, accounts and discourses.

The search for an ethical subtract of political memory as well as questioning the perspectives of Law regarding the phenomena of remembrance allow for countless appropriations. It is possible, and even indispensable, to evaluate an approximation between memory and truth, analyze the bonds between memory, forgetting and pardoning, situate remembrance from the notion of time and belonging and, among other meanings, examine the ethical appeal of the memory of those who are closest to us. All of these issues, which are interconnected, are fundamental to the definite the delineation of the Right to Memory (and to understand the dichotomous appropriations of the Right to Memory).

In effect, as a first appropriation, the alleged connection between memory and truth, although internationally consolidated, may be the most difficult significance in 
giving meaning to the Right to Memory and Truth. The problematic of material truth within the criminal process, for example, is not new (and it is equally challenging), as it is solely possible to refer to this title the impossibility of ignoring, in collecting proof, individual guarantees that favor a desired truth. In other words: truth cannot happen at any price (HASSEMER, 1984). If the very own dynamics of process come across its own pretension of truth, what can be said about the political building of truth? Wouldn't the Nuremberg Trials have shown that truth, at times, obscures accounts, narratives and new appropriations of the past? (GOLDENSOHN, 2005; SNYDER, 2012). The question thus remains: what memory is it possible to discuss while the course of memory is still being built?

As a second appropriation, is possible to say that the relation between memory, forgetting and forgiveness are equally challenging. Are they opposing concepts? Or, on the contrary, do they constitute the same dynamics resumed from the past (OLIVEIRA, 2009)? Does the Right to Memory and Truth ally with an unsurpassed need for punishment of the violators of Human Rights? If so, what would justify the political celebration of amnesties? On forgiveness, is it enough to remember distinct understandings given to it by Hannah Arendt and Jacques Derrida: for the German philosopher forgiveness is a shared act, destined to stop the continuity of what until then seemed irreversible, thus revealing itself as a political (re)action immersed in an idea of alterity; for the French philosopher, born in Algeria, forgiveness is an appeal, immune to conditions or acceptance and unaware of any perspective of reconciliation. Therefore, immune to institutionalizations.

A third challenge can be observed in the connection between time, belonging and truth. The questions regarding the meaning of time imply a debate on the meaning of Law itself (OST, 2005). In the same way, it resumes the discussion over the limits of truth and its connection with the idea of the past (ELIAS, 1998). Furthermore, what is remembrance if not reaffirming one's own notion of belonging? How individuals and society can build a notion of political memory? This is about the still incipient understanding of the phenomena of remembrance and, by reflex, the understanding of the extension o Right to Memory and Truth (ELIAS, 1994). 
Besides these possibilities, however, two other reveal themselves to be equally necessary, and define the analysis plan proposed herein: understanding political remembrance - and the Right to Memory and Truth - as an ethical refusal of the time of progress (which implicates the encumbrance, not always tolerated, to abandon the almost mythical idea that dealing with the past is enough to reach a redeeming future) and accepting the insufficiencies of Law, in its classic positivist view, to fully develop and affirm the Right to Memory and Truth (which imposes another cost: admitting that another Law, fully new, is needed to deal with the dynamics of political memory); here is where a connection between the Right to Memory and Truth and Fraternal Law begins.

\section{THE MYTHICAL ASSURANCE OF POLITICAL MEMORY: THE PROGRESS ALSO DESIRED FROM MEMORY}

An apparent belief lives in common sense - a perspective that is many times transferred to the affirmation of political memory - that recovering the past and giving meaning to facts from the past fatally culminate in a new time, stripped from the barbarism which once defined it. The role of a redeemer is given to memory upon being discussed again and introduced in political debates, as if it could, on its own, implicate a new social, political and legal dynamics. The redemption of memory would be inevitable; thus, recovering the past is an unpostponable measure. There is a sort of myth of truth and faith in memory. Only through (re)designed truth and memory, would the present have a real meaning and some hope would be given to the future. Regarding this aspect, it is enough to remember the slogan repeated by the Brazilian State itself, and used by The Civil House of the President of Brazil in the project called Memories Revealed, coordinated by the Brazilian National Archives: "So we shall not forget. So it shall never happen again" (MEMÓRIAS REVELADAS, 2017).

Reliving the past thus emerges as an apparent prophecy: memory would allow the future to overcome the violence of the past, avoiding their repetition. However, 
would this assurance be so simple and tangible? Is there an example in history capable of confirming that the exercise of political memory has avoided the repetition of violent practices from the past, or that the present time, thanks to remembrance, has overcome the exclusions that the past witnessed?

Two examples - and there are many others - seem to deny this attempt to see memory as a promise of progress and evolution. An alert is necessary: the mentioned examples are not consequence of a dictatorship; instead of this they only reflect two events that can contribute to understand the impossibility of overcoming of the violence and barbarism in the human history. The choice has a reason: to demonstrate (I) that the Right to Memory and Truth needs to be continuously constructed as an ethical appeal and (II) that the political memory, that means a memory politically built, preserving the idea that the memory is important for a social identity and belonging when it is not inclusive (fraternal) - are incapable to avoid the repetition of violence and attacks against Human Rights.

The first example to define the insufficiency of remembrance as reassurance of progress - or "so it never happens again" - deals with emblematic Tuskegee experiment. During forty years (from 1932 to 1972), the U.S. Public Health Service conducted a study with human beings from Macon County in the state of Alabama. The "Tuskegee Study" (Tuskegee Study of Untreated Syphilis - TSUS) was named after the research center where it took place (Tuskegee Institute), and studied the effects of the evolution of syphilis in the human body.

A remark is necessary: the time when the study took place, between 1932 and 1972 (UNIVERSITY OF VIRGINIA, 2017). Why is this important? Because it started before World War II, and survived such armed conflict. What does that mean, besides representing a statistic data? It represents human inability in dealing with the vestige of its barbarism. How can that be claimed? The end of World War II imposed upon the world - and this is affirmed by memory - the certainty that the political and legal rationale in force before World War II was unable to avoid violent acts as a routine of power. Barbarism, through extermination, mass deportation and killings of ethnic groups, was an accepted practice for the State. 
The ethical abysm lead philosophy to reconfigure its paradigms, so that is could give any meaning (and some assurance) to human relations: Theodor Adorno, with his imperative that Auschwitz is not repeated, Emmanuel Levinas, in his understanding of alterity as a means to questions the idea of domination and Walter Benjamin, in the new roles he confers to players and to the cycle of history, illustrate with precision the distress that violence praised. However, not even the rawest exposure of an institutionalized violence dynamics was enough to stop ethically blameworthy experiments from being resumed.

We go back to Tuskegee where the effects and progress of syphilis in the human body were supposedly being examined. This apparently commendable purpose clashed with the means used to study the illness. Around 600 black men were rounded up for the study, of which 399 had syphilis and 201 did not (GOLDIM, 1999). They were told that they would be examined because they had "bad blood" . However, none of them was informed of the amplitude of the study; they were also not told their real diagnosis, so that infected participants did not know that they carried the disease (WHITE, 2008), its effects, and were not aware that, although participating in a medical research, they would never receive treatment (USA, 1973). The real purpose was the pure clinical investigation of the reactions of the human body to the harmful consequences of the disease since prognosis and clinical manifestations were unknown at the time.

Justification based on the inexistence of an effective and proven treatment for syphilis collapsed in the 50s when treatment for the disease was discovered. However, all patients involved in the study - even after the horrors after World War II had been presented to the world - continued to be subjects without receiving any help or treatment. To make matters worse, "all health institutions in the United States of America received a list with the names of participants in an attempt to avoid these individuals from getting treatment" (GOLDIM, 1999).

\footnotetext{
${ }^{5}$ The expression "bad blood", used at the time to recruit individuals willing to participate in the study, referred to several diseases including syphilis, anemia and fatigue. (CDC. U.S., 2015). 
Besides bringing up the necessary debate over the limits of studies involving humans, the Tuskegee study, which lasted until 1972, present a clear alert as to the salvation belief on political remembrance: no even after World War II with the revelation of the monstrosities of death camps and with clear evidence that legal and political dynamics accepted the dissemination of excluding policies and associated to the most repulsive violent practices, was it able to confer a meaning to the future. It was remembered; it is remembered still today; it will be remembered forever. However, that does not seem to be the announcement of a redeeming future. After all, concentration camps were not enough to avoid the perpetuation of Tuskegee.

After the denouncement of the harms of Tuskegee, would this case be, as many others that had been overcome and remembered, an assurance and announcement of memory as an ethical rule to make sure violence is not repeated? The tale of progress - a typical aspiration of history - seems to negatively answer this desire. The evidence that violent routines, and attacks against Human Rights, accepted by the State persist are countless: leaking of toxic gas in Bhopal, India, which still awaits for the definition of the responsible individuals (AMNESTY INTERNATIONAL, 2014b); denouncement in 2014 that even 30 years after the United Nations Convention against Torture use of routine police violence persists in over one hundred countries (AMNESTY INTERNATIONAL, 2014) and the United Nations Report on June 4, 2016 informing the existence of slavery: an estimated 21 million people suffering with forced labor (UNITED NATIONS, 2016) are only a few pieces of evidence that remembrance itself does not guarantee overcoming the legacy of violence that has characterized the past.

A second example, unarguably linked to the comprehension of the human dignity, a target of so many attacks, also by the State: the classic Valladolid Debate. With the discovery of America, a new rationality was demanded from Eurocentric appropriations. There was a different world, with its own dynamics, to be understood and to be dominated.

In order to justify European dominion, with the consequent attempt at indigenous enslavement, its absolute submission started to be defended: there would 
not be, in the way Indians acted and from their cultural dynamics, traces of a typically human rationality. The barbarities that were committed under this pretext against the indigenous peoples reached the point where Catholic monk Bartolomé de Las Casas produced a report to the Spanish king Carlos $V$ explaining the state of violence, which resulted in the king creating a council to investigate such reports. Its name because a history legacy today known as the Valladolid Debate. On one side of the debate was Bartolomé de Las Casas defending the human nature of the Indians; on the opposite side was Juan Guinés Sepúlveda, admitting conquest and submission of indigenous peoples (LAS CASAS, 2008). A definite judgment was not reached, so there was no "winner". However, Spain recognized the barbarism and in 1573-23 years after the beginning of the Valladolid Debate - the country disciplined the manner in which the expansion of its empire would take place, imposing restrictions to the use of force against native American (GOMES, 2006).

Did the Valladolid Debate allow for overcoming the barbarism it reported? Did it avoid the continuous and successive exploration and exclusion of indigenous peoples? Did it allow for a uniform understanding of alterity? Did the Other take on a preponderant position on political decision making? Again, memory seems to fail the aspirations set upon it. Remembrance means more than resuming the past, it demands not only the inventory of barbarism, but creating new paradigm which are capable of establishing a new dynamic in building political thinking; otherwise, the future is destined to repeat the violence of the past even with remembrance. Maybe that helps to explain why some centuries after Valladolid the extermination of natives in Brazil persists: 137 deaths in 2015 (CIMI, 2015), as well as why in Canada (CANADA, 2015) the rights of indigenous peoples over land which will be flooded with the building of a dam were ignored (AMNESTY INTERNATIONAL, 2016), and, why it is so hard to turn away the xenophobic retaliation (ONU, 2016b) in certain countries against refugees (AMNESTY INTERNATIONAL, 2016; ONU, 2016) in a clear position of vulnerability (UNHCR, 2018). Have Valladolid allowed, once they are remembered, for a new perspective on the Other? 
The repetition of the violence and attacks against Human Rights in new shapes, words and colors, after many years of wars and other examples of violence can prove that political memory, without an inclusive construction, is fallible and not enough to overcome the past of abuses and barbarism. The alert of the past, in many cases, was not sufficient to a new and peaceful future. Instead of this, as the abovementioned situations reveal, the cycle of violence is still in course and new victims are generated every day with the same speech that allowed, in the past, the refuse of the Others.

Regardless of the pessimistic scenario in which remembrance is announced, maybe it is time to understand that memory cannot be chosen as the receptacle of all dreams for a harmonized world willing to stop its own dynamics of violence in the future. Maybe it is time to comprehend that memory also has limits. Not everything can be expected from political remembrance, and even if it sounds paradoxical, it is good that it be this way, because memory is, in itself, the negation of historical linearity and presumably immutable affirmations. It is a process, continuously in course, endlessly renewable.

\section{TIME OF MEMORY VERSUS TIME OF PROGRESS: AN ETHICAL COMPREHENSION OF MEMORY}

Thus, maybe it is time to understand that memory, from the past, is an alert for the present time, like a loud siren demanding, today, overcoming barbarism. The challenge lies in understanding Right to Memory as something separate from a mere redesigning of historical narratives for a redeeming future. This wrong idea of progress is what allows - in the inclusion that negates - for joint appropriations of the past. That might partially explain the existence of such antagonist understanding when one talks about Right to Memory and Truth in Brazil. Maybe the great question to this problem is: have opposing views ever given the opportunity for conciliation? 
When memory is seen as a possibility for progress, it also commits the same vices of History: imprisoning the past in a normative understanding, in which truth, already given by the facts that have taken place, would solely accept the discourse of the winners or the appropriations of facts in compliance with a previously made choice. Thus, it is possible to understand that chronological divisions say little to memory, simply because the facts that have already taken place compartmentalize time, but don't define it or circumscribe it. On the contrary, they continually irradiate, though silently, their effects over the present time. According to Halbwachs, "We are victims of an illusion when we imagine that a higher amount of events or differences means the same as a longer time. That means forgetting that events divide time, but do not fulfill it" (HALBWACHS, 2006, p. 143).

The time of memory - continuously redesigned - is not enough for the aspiration that it will be enough for a redeeming future. The time of progress, of this imagined magical future, is the aspiration that it cannot belong to remembrance as an ethical rule. Right to Memory and Truth has room only to remember the reports of the one who have lost and discourses suffocated in the past. However, it does not remember them so that they are enough on their own. They are repositioned as a disquieting warning to the present time (now is the future that was once dreamt of in the past).

Thus, Right to Memory and Truth can only lay its foundations over an ethical basis that refuses to repeat the linear progress wanted by History and the idea that one discourse may prevail over others. The linearity of the descriptions, a compartmentalized understanding of time, the alleged exemption that it takes before the past, the announcement of pretense truths, justified by auto-referring its historical allegation, and even the imagined temporal organization of events succession - as if it were possible to limit time in a space and explain human evolution under the idea of an infinite game of cause and consequences (thus a typical positivist promise) - reveal the belief of History in its own strengths. It is not difficult of understand the revolutionary promise of History based on positivist dogmas of the $19^{\text {th }}$ century and of great part of the $20^{\text {th }}$ century. Thus, it is equally acceptable that politics and law, without doubts, 
would build their own meanings based on this commitment to progress. This belief, however, loses it intention when faced with a simple question, conceived according the ethical proposal of Walter Benjamin: what history remain to the victims, to the ones that were excluded, the marginalized, the rejected, the minorities, those who have been exposed to acts of violence, forced to fall silent?

Understanding the possibilities of this new History and this memory, inclusive and humanized, require a new paradigm (which, as seen above, Right to Memory and Truth itself seems to ignore). The rupture is proposed by Walter Benjamin in his thesis On the Concept of History, as explained by Michael Löwy: "Benjamin opposes the qualitative conception of infinite time (...). 'which comes from the romantic messianic' and according to whom life of humanity is a process of accomplishing and not only of happening towards an infinite empty time (...) a characteristic of the modern ideology of progress" (LÖWY, 2005, p. 21).

The ethical fundamental of Water Benjamin admits rupture from the linearity intrinsic to historical and juridical positivism so that a new understanding is given to History itself. Historical evolution is not connected to any idea of a future progress; on the contrary, a proclaimed progress only hides the continuous onset of catastrophes. This situation deals with a previous warning: that a belief that memory will prevent the repetition of barbarism in the future, barbarism keeps being reproduced in the present. Suspending this process characterizes the instant of revolution, the moment of emancipation that equally defines messianic time itself (LÖWY, 2005).

The mistake of history, for Benjamin, is the announcement that brings truth itself, always taken as a synonymous of an imagined progress (wouldn't it be the same naive mistake on which an affirmation of a Right to Memory and Truth lies?): "The past brings with it a mysterious index, which impels it to redemption. Aren't we touched by a breath of air that has been breathed before? Aren't there, on the voices that we hear, echoes from voices that have gone mute?" that is what Benjamin writes on his Thesis II to finally conclude that "Someone is waiting for us. In this case, as with every generation before, we were given a fragile messianic strength for which the past addresses a claim. This claim cannot be rejected with impunity" (BENJAMIN, 2008, p. 
223). The proposed redemption lies on the individual and it is impossible that they claim any personal happiness not associated with "the redemption of their own past, the accomplishment that could have been but didn't happen" (LÖWY, 2005, p. 48).

With that, Todorov's alerts on the abuse of memory gain a strong pertinence. After all, recovering the past, in itself, says nothing: "no hay razón para erigir un culto a la memoria por la memoria; sacralizar la memoria es otro modo de hacerla estéril. Una vez restabelecido el passado, la pregunta debe ser: ¿para qué puede servir, y con qué fin?" (TODOROV, 2000, p. 33). To Benjamin, the answer seems clear: for the continuous cycle of progress from the perspective and remembrance of violence and the victims made in the past, an evident ethical appeal to a new present.

Benjamin equally criticizes the historical appropriation of truth, which affirmation is also submitted to historicity: there is no final word on the past or an uncontroversial historical truth; equally, there is no history that can be imposed nor a new history built from an ideological basis, which takes from the individual his condition of historian of his time (LÖWY, 2005). It is not for another reason that Benjamin clears in his Thesis VI that "historically articulating the past does not mean knowing it 'as it really happened'. It means to take hold of a reminiscence, just as it shows at times of danger" (BENJAMIN, 2008, p. 224).

In the understanding of Benjamin it is clear that remembering the victims means meeting all of them, without exceptions, because only this way the messianic plan, with the power it deposits in each present time, would be the redemption, the overcoming of barbarism and the ruins of the progress of history. Therefore, and ethics of memory must deal with all reports that make up the past; there is no other way to break the flow of progress, and there will not be another way to reconcile versions and solve conflicts.Paradoxically, from this perspective another concern of Todorov is answered: it is not possible to choose the victims that have a right to memory and truth; all of them must be remembered, regardless of the political filters that the present may establish (TODOROV, 2000, p. 57). 
Benjamin's Thesis IX, certainly the most widely known and which reference to painter Paul Klee has become classic ${ }^{6}$, states that the angel of history, upon looking at the past, cannot relieve the dead or fix the destruction of its barbarism. His wings remain open by a storm that drags him into the future, while the destruction keeps growing. This storm is progress itself.

The criticism to the classic conception of History is evident, and it consists in the idea of a continuous progress, that is part of the facts that follow human evolution. A History that is not worried about the costs paid for the creation of this path, ignoring the actors of time, victimized and forgotten, and not caring about the ruins of barbarism, which in favor of a small number of winners sacrificed an unknown number of beaten.

These sacrifices are important for this new history, which is concerned about the total amount of ruins, those that the angel of history observes in astonishment while he is pushed towards and unknown future. The angel has only once certainty: the ruins of the past remain and can never be forgotten. It is necessary to stop the continuous and devastating flow of progress; it is necessary to reconfigure History and commit it to the beaten and the victims, with the unshakable ethical claim that the catastrophes if violence impose.

The time of progress - and its destructions and violence - opposes the time of memory, which is qualitative and discontinuous - Thesis XVII (BENJAMIN, 2008, p. 231), which aims only at uniting the past and the present, without prophesizing any end to history. History, relived my memory, will this find its starting point and its arguing affirmation, a characteristic that is needed to stop all destruction that the idea of progress has accepted. Then it will be redeeming. And for that, each historical subject shall be a part of its messianic announcement.

For Walter Benjamin, this other historical face is the time of now, in which the past invariably appears in the present, in a subtle movement of interruption of the infinite course of time of history. It is not about a mere remembrance but recovering the course of actions that were interrupted by the past, as a sound alert for the present

${ }^{6}$ This regards the association between present, past and future from the interpretation given to the work Angelus Novus, from Paul Klee. 
time. This alert is not given to a moment that has yet to arise. Memory is continuously resumed to stop advancements of progress in each new present time. However, the visit that the past pays the present is not aleatory. On the contrary, it reports the catastrophe as an indissociable condition of the human course, debris over which we must rise, so that justice is not reached, a new history. It is an endless process.

\section{WHAT LAW CAN UNDERSTAND THE POLITICAL MEMORY?}

The classic positivist conception of Law, as an imagined science, does not indicate an effective potentiality to answer the plural, continuous and inclusive dynamics that define remembrance. The political space demanded by memory, in which all discourses become a part in building their meanings (because on the contrary the rite of History progress will simply be repeated), does not find in the usual appropriations of Law the viability if needs.

The opposing discourses regarding building Right to Memory and Truth show the difficulty in attributing meaning to the past. While the opposition persists, barbarism persists, forever tolerated by the idea of progress. To cease the excluding repetition of History, Law would have an important role. However, nothing different can be expected from Law as it is today, with its censurable activisms and with the repeated affirmation of its also violent dynamics (GIRARD, 2008).

The rupture desired by memory, in its political aspiration, demands the possibility of reconciliation, inevitably thought of in a joint manner (this is the definite horizon in declaring that there is a political memory). If not this way, with the conjugation of all possible accounts, memory will be circumscribed to the same cycle of linear excluding History. The selectivity of memory - which also comes from its political characteristics since it is defined by time and by the possibilities that define it - does not allow for victims, accounts, and previous compositions favoring and imagined future (which in the end would represent nothing more than a new color given to admitting progress) to be chosen. Selectivity only means, in the present time, taking once again all paths taken in the past, which await for a new present in order to reveal 
themselves as a warning against repeating barbarism. Denying versions and accounts equals to selecting the winners accepted by History. Selectivity, therefore, is not exclusion.

Considering the Right to Memory and Truth as a Human Right means acknowledging the unsatisfactory constitution of Law itself in accepting memory as a new meaning. The insufficiencies of Law in protecting political remembrance, beyond pointing the incomprehension of memory itself, seem to offer a new perspective over the possibilities of Law itself. But what meaning of Law can allow for an inclusive comprehension of memory itself, and then accept a political understanding of the Right to Memory and Truth?

The first self criticism: (a) if Law maintains its current codes, if it remains closed to diversity and plurality, insisting in building its exclusive impressions of the human and determined to carry on, in building its dynamics, the same History of winners, the Right to Memory and Truth will be solely limited to the instants allowed by Transitional Justice, where memory is considered as an opportunity to resume the past, selective and close to the understanding admitted by the march of progress, which will tolerate repetition of dichotomist appropriations, or (b) if Law admits, to any degree - a perspective that Transitional Justice bears in its own foundation - political conciliation from memory, it will be able to escape historical linearity, and then admit that the past is the warning for the present time. Thus, memory itself will no longer represent progress, and all accounts, because all mater, will allow for a reconfiguration of Law, which is now shared amongst equals and sworn as a whole. A typical Fraternal Law in which the moment of decision is no longer the intransigent lead role in legal decisions, and where a new understanding of Law is accepted; because, after all, Law is Politics (RESTA, 2004).

The second self criticism: (a) if Law ignores the ethical appeal of remembrance and due to reluctance or convenience ties itself to binary hermeneutic concepts, which are authentic dichotomies, memory will remain a possibility, an eternal promise to the coming future, while the cycle of barbarism repeats itself in the assumption of following the path to progress (as abovementioned explained); however, (b) if Law opens up to 
the plurality of speeches (thus to political experience) it will turn the violence under which it was created into the dimension of double ties admitted by Resta: will Law be able to transform violence originating from legitimacy into politically built remembrance. In summary: Law should open up to time, understanding that it is also an heir to the past, and that it does not hold the magical power to condense time, but it is given the prerogative to conjugate accounts - all accounts - into a new present time (RESTA, 2013), because it is here that the past is announced, not for a redeeming future, but for today.

From this self criticism, it is possible to clearly conclude that the idea of a Transitional Justice as a privileged space for remembrance brings along a real paradox. Transitional practices are undeniable proof of the insufficiency of the Right to Memory: if Law were to actually concede room and understanding to political remembrance, why would it be necessary to (re)instate an exceptional legal order within legal order itself? Why didn't Law, by its own codes, did not stop barbarism or did not admit, after barbarism was overcome, remembrance, punishment to responsible perpetrators and the reconfiguration of the present time? Therefore, there is room for the Right to Memory and Truth. However, to understand the totality of its dimension, Law - whose current codes do not allow for the meanings desired by memory - needs to reconfigure its understanding of the human, life, and time. Meanwhile, we keep on believing in the inexorable and libertarian course of progress.

\section{CONCLUSION}

The perspective built in this Article validates the hypothesis that the affirmation of the Right to Memory and Truth is insufficient, by itself, to protect Human Rights. The understanding of the Brazilian Constitutional Court, in comparison with the InterAmerican Court of Human Rights position, indicates the dichotomy that, particularly in Brazil, define the Right to Memory and Truth. 
The example of transitional Brazilian practice, unmistakably destined to inventory the violence wounds left by the military dictatorship regime, clashes with an unsatisfactory dichotomy: those who only admit the recovery of violent routines disseminated and accepted by the State on one side and on the other side those who accuse objectors of the military dictatorship regime of aiming to implement their own political agenda, opposed to democracy. This conceptual appropriation - usual in history - is wrong because it is selective and forget that the past was built in a shared time, with equals and, in this way, the dichotomy stops the opportunity for conciliation.

There are two obstacles that all States needs to face when the Right to Memory and Truth needs to be juridically proclaimed: (i) build a memory ethics that is able to confer meaning to the mnemonic phenomenon and to its political configuration and (ii) understand the limits and real possibilities that Law itself confers to the perspective of remembrance, that is, if Law is sufficiently prepared and opened to combining plural testimonies, accounts and discourses.

Some examples can confirm that the past of violence against Human Rights can be repeated if the Law keeps its own and traditional way of understanding the political memory, representing the human inability in dealing with the vestige of its barbarism: the Tuskegee Study, that started before World War II and survived such armed conflict, and the discussion, on Valladolid Debate, about the human nature of the Indians. However, after Tuskegee and Valladolid Debate, the violence persists and the memory seems to fail the aspirations set upon it: the tragedy in Bhopal, India, which still awaits for the definition of the responsible individuals; the routine of police violence that persists in many countries; the existence, today, of slavery and forced labor; the extermination of natives in Brazil persists; in Canada the rights of indigenous peoples over land which will be flooded with the building of a dam were ignored and the xenophobic retaliation in certain countries against refugees in position of vulnerability.

The political memory, therefore, conceived as a memory defined in the same public space, between people with the same notion of belonging and identity and opened to reconciliation, is not a promise of progress or evolution. The exercise or the 
affirmation of the Right to Memory and Truth don't overcome, by itself, the repetition, on present time, of violent practices from the past. The political memory is not a guarantee for democracy. Remembrance means more than resuming the past, it demands not only the inventory of barbarism, but creating new paradigm which are capable of establishing a new dynamic in building political thinking.

According to Walter Benjamin, Right to Memory can only lay its foundations over an ethical basis that refuses to repeat the linear progress wanted by History and the idea that one discourse may prevail over others. Historical evolution is not connected to any idea of a future progress; on the contrary, a proclaimed progress only hides the continuous onset of catastrophes. This situation deals with a previous warning: that a belief that memory will prevent the repetition of barbarism in the future, barbarism keeps being reproduced in the present.

At the same time, according Tzvetan Todorov, it is not possible to choose the victims that have a right to memory; all of them must be remembered, regardless of the political filters that the present may establish. Only this ethic perspective, willing to bring all victims to the stage of remembrance - and which refuses to give voice only to documenting the history of the winners or to reports previously elected as correct or acceptable - will allow for a joint building of a Right to Memory.

The insufficiencies of Law in protecting political remembrance offer a new perspective over the possibilities of Law itself, that the present study define in two ways of self-criticism. The first self-criticism: (i) Law can maintains its current codes and remains closed to diversity and plurality; the consequence: the Right to Memory and Truth will be solely limited to the instants allowed by Transitional Justice, where memory is considered as an opportunity to resume the past, which will tolerate repetition of dichotomist appropriations, or (ii) Law can admits a perspective that Transitional Justice bears in its own foundation and then admit that the past is the warning for the present time; the consequence: memory itself will no longer represent progress, and all accounts will allow for a reconfiguration of Law, which is now shared amongst equals and sworn as a whole. A typical Fraternal Law, according to Eligio Resta. The second self-criticism: (i) Law can ignore the ethical appeal of remembrance 
and due to reluctance or convenience ties itself to binary hermeneutic concepts, which are authentic dichotomies; the consequence: the memory will remain a possibility, an eternal promise to the coming future, or (ii) Law can opens up to the plurality of speeches about the same past; the consequence: the prerogative to conjugate all accounts into a new present time, because it is here that the past is announced, not for a redeeming future, but for the present.

Transitional practices are undeniable proof of the insufficiency of the Right to Memory and Truth: if Law were to concede room and understanding to political remembrance, it would not be necessary to (re)instate an exceptional legal order within legal order itself. Therefore, the construction of political memory needs a conciliatory meaning to the Right to Memory and Truth and a different comprehension of Law, based in a new ethical appropriation.

\section{REFERENCES}

AMNESTY INTERNATIONAL: La Tortura em 2014: 30 años de promessa incumplidas. Available at: <https://anistia.org.br/wp-content/uploads/2014/09/Latortura-en-2014.pdf>. May. 2014. Access on: Aug. 30, 2019.

<https://anistia.org.br/wp-

30 anos é muito tempo para se fazer justiça. Available at: content/uploads/2015/02/4476_Bhopal_Digest_web.compressed.pdf>. Dec. 2014. Access on: Aug. 30, 2019.

Canadá: barragem de hidroelétrica ameaça comunidades indígenas. Aug. 09, 2016. Available at: <https://anistia.org.br/noticias/canada-barragem-dehidroeletrica-ameaca-comunidades-indigenas/>. Access on: Aug. 30, 2019.

Líderes mundiais 'se esquivam ou não compartilham a responsabilidade' na crise dos refugiados. Sept. 13, 2016. Available at: $<$ https://anistia.org.br/noticias/lideres-mundiais-se-esquivam-ou-nao-compartilhamresponsabilidade-na-crise-dos-refugiados/>. Access on: Aug. 30, 2019.

BENJAMIN, Walter. Obras escolhidas: Magia e técnica, arte e política: ensaios sobre literatura e história da cultura. 7. ed. São Paulo: Brasiliense, 2008.

BOBBIO, Norberto. Estado, governo, sociedade: para uma teoria geral da política. 10.ed. São Paulo: Paz e Terra. 2003. 
BRASIL. Lei no 12.528, de 18 de novembro de 2011. Cria a Comissão Nacional da Verdade no âmbito da Casa Civil da Presidência da República. Available at: <https://www.planalto.gov.br/ccivil_03/_ato2011-2014/2011/lei/112528.htm>. Access on: Aug. 30, 2019.

. STF - Supremo Tribunal Federal. Arguição de Descumprimento de Preceito Fundamental no 153.Argte.: Conselho Federal da Ordem dos Advogados do Brasil - OAB. Argdos.: Presidente da República e Congresso Nacional. Relator: Min. Eros Grau. Brasília, 24 de abril de 2010. Available at: < http://redir.stf.jus.br/paginadorpub/paginador.jsp?docTP=AC\&doc/D=612960>. Access on: Aug. 30, 2019.

CANADA, Truth and Reconciliation Commission of Canada. Honouring the Truth, Reconciling for the Future. Summary of the Final Report. 2015. Available at: $<$ http://nctr.ca/assets/reports/Final\%20Reports/Executive_Summary_English_Web.p df>. Access on: Aug. 30, 2019.

CDC. U.S. Public Health Service Syphilis Study at Tuskegee - The Tuskegee Timeline. Dec. 22, 2015. Available at: <http://www.cdc.gov/tuskegee/timeline.htm>. Access on: Aug. 30, 2019.

CIMI. Violência contra os Povos Indígenas no Brasil. 2015. Available at: $<$ http://www.cimi.org.br/pub/relatorio2015/relatoriodados2015.pdf>. Access on: Aug. 30, 2019.

Corte Interamericana de Direito Humanos - CORTEIDH. Caso Gomes Lund e Outros (“Guerrilha do Araguaia") vs. Brasil - Sentença de 24.11.2010. Available at: $<$ http://www.corteidh.or.cr/docs/casos/articulos/seriec_219_por.pdf>. Access on: Aug. 30, 2019.

. Caso Herzog y Otros

Sentença de 15.03.2018. Available at: <http://www.corteidh.or.cr/docs/casos/articulos/seriec_353_esp.pdf>. Access on: Aug. 30, 2019.

EBOLI, Evandro. Prioridade da Comissão da Verdade é localizar desaparecidos. 0 Globo, Rio de Janeiro, 02 mar. 2012. Available at: $<$ http://oglobo.globo.com/brasil/prioridade-da-comissao-da-verdade-localizardesaparecidos-4129759>. Access on: Aug. 30, 2019.

EDLER, Sandra. Luto e melancolia: à sombra do espetáculo. Rio de Janeiro: Civilização Brasileira, 2008.

ELIAS, Norbert. A Sociedade dos Indivíduos. Rio de Janeiro: Jorge Zahar, 1994. 
Sobre o Tempo. Rio de Janeiro: Jorge Zahar, 1998.

TUSKEGEE ADVISORY PANEL - Final Report of the Tuskegee Syphilis Study Ad Hoc Advisory Panel. Available at <http://biotech.law.Isu.edu/cphl/history/reports/tuskegee/tuskegee.htm>. Access on: Aug. 30, 2019.

GAGNEBIN, Jeanne Marie. História e narração em Walter Benjamin. São Paulo: Perspectiva, 2009.

GIRARD, René. A violência e o sagrado. 3. ed. São Paulo: Paz e Terra, 2008.

GOLDENSOHN, Leon. As entrevistas de Nuremberg: conversas de um psiquiatra com os réus e as testemunhas. São Paulo: Companhia das Letras, 2005.

GOLDIM, José Roberto. $O$ caso Tuskegee: Quando a ciência se torna eticamente inadequada. 1999. Available at: <http://www.ufrgs.br/bioetica/tueke2.htm>. Access on: Aug. 30, 2019.

GOMES, Renata Andrade. "Com que direito?": Análise do debate entre Las Casas e Sepúlveda - Valladolid, 1550 e 1551. 2006. 116f. Mestrado em Direito - Pontifícia Universidade Católica de Minas Gerais, Belo Horizonte. Available at: $<$ http://www.biblioteca.pucminas.br/teses/Direito_GomesRA_1.pdf>. Access on: Aug. 30, 2019.

HALBWACHS, Maurice. A memória coletiva. São Paulo: Centauro, 2006.

HASSEMER, Winfried. Fundamentos del derecho penal. Barcelona: Bosch, 1984.

LAS CASAS, Frei Bartolomé de. O paraíso destruído: A sangrenta história da conquista da América Espanhola, Porto Alegre: L\&PM, 2008.

LÖWY, Michael. Walter Benjamin: aviso de incêndio: uma leitura das teses "Sobre o conceito de história". São Paulo: Boitempo, 2005.

OLIVEIRA, Antônio Leal de. O perdão e a reconciliação com o passado em Hannah Arendt e Jacques Derrida. Revista Anistia Política e Justiça de Transição Ministério da Justiça, Brasília, n. 1, p. 203-227, 2009.

ONU. Países têm que aprender a lidar com diversidade e garantir direitos dos refugiados e migrantes. Sept. 19, 2016. Available at: <https://nacoesunidas.org/onupaises-tem-que-aprender-a-lidar-com-diversidade-e-garantir-direitos-de-refugiadose-migrantes/>. Access on: Aug. 30, 2019. 
Mais de $\mathbf{3 0 0}$ mil refugiados e migrantes atravessaram o Mediterrâneo em 2016, diz ACNUR. Sept. 21, 2016. Available at: <https://nacoesunidas.org/maisde-300-mil-refugiados-e-migrantes-atravessaram-o-mediterraneo-em-2016-dizacnur/>. Access on: Aug. 30, 2019.

OST, François. O tempo do Direito. Bauru, SP: Edusc, 2005.

PEREIRA, Rômulo Bini. Direitos Humanos. Estadão, São Paulo, 07.06.2016. Available at: <http://opiniao.estadao.com.br/noticias/geral,direitos-humanos,10000055628>. Access on: Aug. 30, 2019.

MEMÓRIAS REVELADAS - Projeto Memórias Reveladas - Centro de Referência das Lutas Políticas no Brasil (1964 -1985). Available at: <http://www.memoriasreveladas.gov.br>. Access on: Aug. 30, 2019.

RESTA, Elígio. Direito Fraterno. Santa Cruz do Sul: EDUNISC, 2004.

Diritto Vivente. Roma: Editori Laterza, 2013.

RICOEUR, Paul. A memória, a história, o esquecimento. Campinas, SP: Editora da UNICAMP, 2007.

SNYDER, Timothy. Terras de Sangue: A Europa entre Hitler e Stalin. Rio de Janeiro: Record, 2012.

TODOROV, Tzvetan. Los abusos de la memória. Barcelona: Paidós, 2000.

UNITED NATIONS. Report of the Special Rapporteur on contemporary forms of slavery, including its causes and consequences. July 4, 2016. Available at: $<$ http://digitallibrary.un.org/record/847436/files/A_HRC_33_46-EN.pdf?version=1 >. Access on: July 07, 2018.

UNITED NATIONS HIGH COMMISSIONER FOR REFUGEES (UNHCR). Desperate Journeys: January 2017 - March 2018. March, 2018. Available at: <https://data2.unhcr.org/en/documents/download/63039>. Access on: Aug. 30, 2019.

UNIVERSITY OF VIRGINIA. Final Report of the Tuskegee Syphilis Study Legacy Committee. $<\mathrm{http}: / /$ www.hsl.virginia.edu/historical/medical_history/bad_blood/report.cfm>. Access on: Aug. 30, 2019.

USA. Final Report of the Tuskegee Syphilis Study Ad Hoc Advisory Panel Report on charge I. April 24, 1973. Available at: 
<http://biotech.law.Isu.edu/cphl/history/reports/tuskegee/report1.pdf>. Access on: Aug. 30, 2019.

WHITE, Robert M. Challenges in a Narrative About the Tuskegee Study of Untreated Syphilis. Journal of Transcultural Nursing, Thousand Oaks, California, v.19, n.2, p. 105-106, abr. 2008. 